Article

\title{
Examining the Conservative Shift from Harsh Justice
}

\section{Joycelyn Pollock ${ }^{\dagger} * *$, Steven Glassner ${ }^{\dagger}$ and Andrea Krajewski}

School of Criminal Justice, Texas State University, 601 University Drive, San Marcos, TX 78666, USA; E-Mails: sdg60@txstate.edu (S.G.); aek48@txstate.edu (A.K.)

$\dagger$ These authors contributed equally to this work.

* Author to whom correspondence should be addressed; E-Mail: jp12@txstate.edu; Tel.: +1-512-245-7706; Fax: +1-512-245-8063.

Academic Editor: Robert Johnson

Received: 28 October 2014 / Accepted: 10 March 2015 / Published: 19 March 2015

\begin{abstract}
Recently, a political shift has been observed, in that some political conservatives are now advocating, adjusting, or abandoning draconian drug laws, including mandatory minimums, and funding diversion, re-entry, and drug programs. Vocal proponents of this movement include Grover Norquist, Rand Paul, Edwin Meese, and Mark Levin, from the Texas Public Policy Council. Any movement away from the mass incarceration that has characterized the U.S. correctional policy for the last 30 years is welcomed; however, it is important to note carefully the philosophical foundation of the conservative's interest in shifting correctional policy. This paper explores the potential factors contributing to this philosophical shift.
\end{abstract}

Keywords: mass incarceration; diversion; mandatory minimums; rehabilitation; conservative; punishment

\section{Introduction}

Recently, there has been a growing support from conservative politicians, pundits, donors, and think-tank authors for reversing the mass imprisonment policies that have characterized American corrections for the last thirty years. Calls for moderation or complete rollbacks of mandatory minimum sentences and lengthy prison terms, support for reentry programs or diversion programs, and even calls for decriminalization of marijuana have been heard from not only libertarians like Congressman Ron 
Paul, but also staunch conservatives such as former Congressman Newt Gingrich and current Congressman and potential presidential contender Rand Paul. One of the most vocal proponents of this trend is Marc Levin, of the Texas Public Policy Council. His "Right on Crime" movement has increasingly dominated the growing chorus of conservative voices advocating a major shift in correctional policy.

In this paper, we will explore this trend. First, the massive incarceration boom that began in the early 1980s will be described and analyzed, including a discussion of its financial and social costs. The numerous calls for reform from academic and advocacy groups even as the country experienced its historic increase in incarceration rates are also discussed. Then, the emergence of conservative support for "liberal" correctional policies will be detailed, including the "Right on Crime" campaign and its major players. This philosophy will be deconstructed to show the stated and theoretical elements of conservative support. We conclude by questioning whether this philosophical foundation for revising our punishment/corrections approach is a stable base upon which to move forward.

\section{United States: A Leader in Incarceration}

According to the International Centre for Prison Studies, the United States has the highest rate of incarceration across the globe with 707 people per 100,000 in a state or federal correctional institution and/or being confined while awaiting trial [1]. Because of the inclusion of the jailed population, this rate is higher than the Bureau of Justice Statistics recent report which identifies the rate of incarceration in state or federal prisons at 623 people per 100,000 residents in the United States ages 18 or older ([2], p. 6). As we know, the United States' rate of imprisonment is substantially greater than that of other countries around the globe, including the Russian Federation (470 per 100,000), South Africa (294 per 100,000), Iran (283 per 100,000), China (124 per 100,000), France (102 per 100,000), Germany (81 per 100,000), Japan (51 per 100,000) and India (30 per 100,000) [1]. Figure 1 depicts the incarceration rates of several other countries and how they compare to the United States.

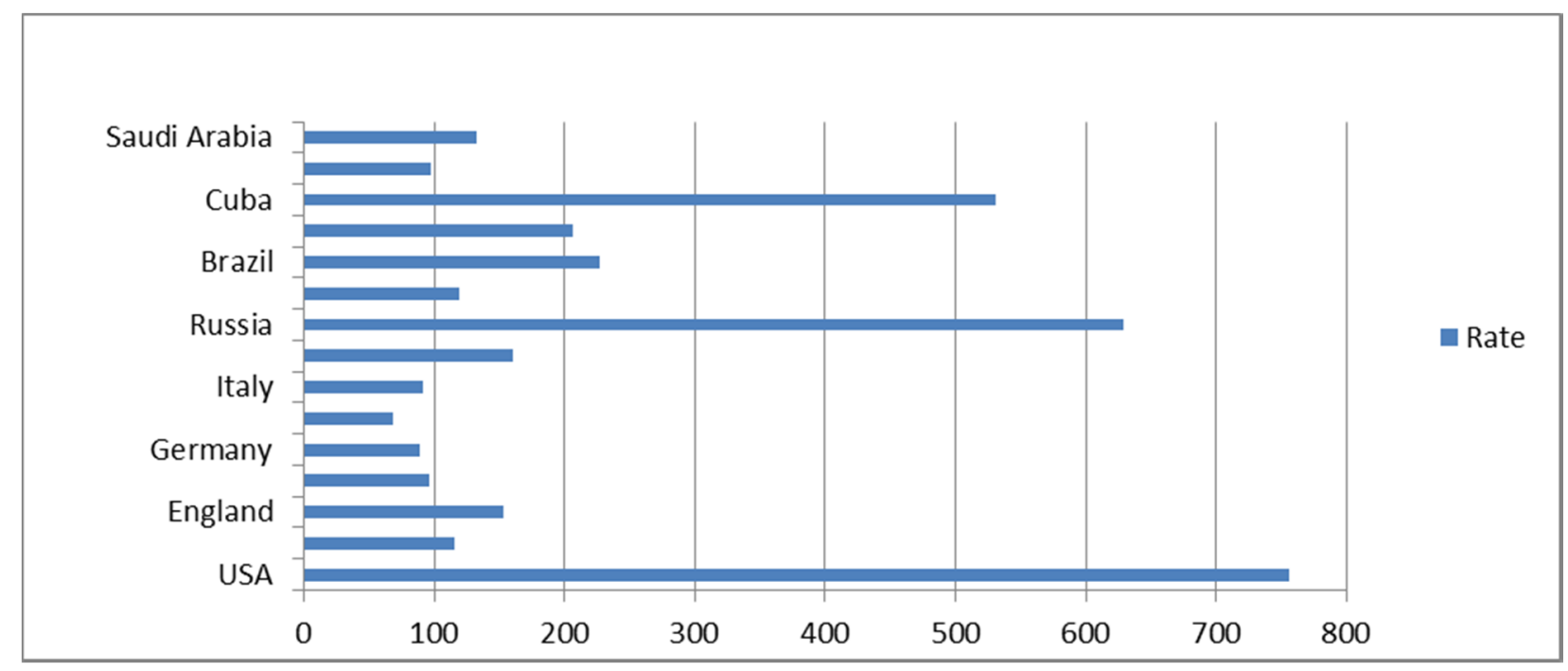

Figure 1. Cross-cultural incarceration rates [1]. 
In the United States, a total of 1,574,741 prisoners (1,463,454 males and 111,287 females) were confined in a state or federal correctional facility by the end of 2013 [2]. Estimates indicate that the federal prisoner population (215,866 prisoners) decreased by 1949 prisoners (roughly 1 percent) in 2013 while the state prison population $(1,358,875)$ increased by 6293 prisoners (approximately 1 percent) from the year prior [2]. This increase marks the end of three years of declining rates (2010-2012), largely attributed to California's release of 15,035 prisoners between the years 2011 and 2013 [3]. This release was prefaced by the Supreme Court's opinion in Brown v. Plata, 131 S. Ct. 1910 (2011) which greatly impacted the incarceration policies of California. Based on this ruling, the California Department of Corrections and Rehabilitation was mandated to reduce its population or remedy the Constitutional violations that were said to be caused by overcrowding within the state's correctional system [3].

The 2013 increase in the prison population restores the pattern of steady increases that have occurred each year from 1972 to 2009 [4]. Figure 2 depicts the imprisonment increase as rates per 100,000 , showing how the 1980 s began an unprecedented shift in punitive practices in this country.

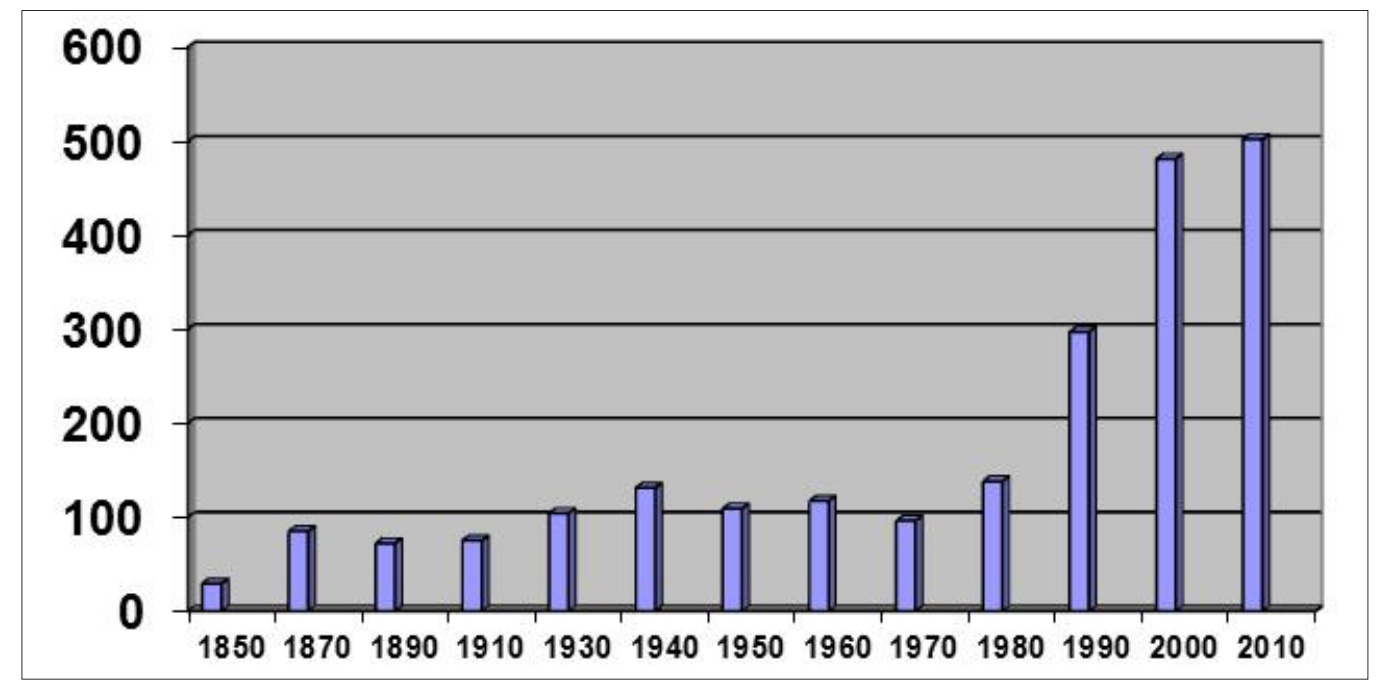

Figure 2. Incarceration rates ([5], p. 23).

Before the 1980s, incarceration rates within the United States were relatively stable and fluctuated under a backdrop of wars, economic booms and busts, and rising and falling crime rates [5-7]. The phenomenon of mass incarceration which began in the 1980s is unique because "the number of prisoners and jail inmates soared, in good times and [in] bad times, independent of whether the crime rate rose or fell" ([6], p. 1). An important point worth noting is the fact that over the past two decades, increasing prison populations across most states have transpired during a steady decrease in the number of reported crimes to law enforcement across the country [5].

Incarceration rates (the number of people in prison or jail per capita) are a function of a number of underlying causes, including the proportion of convicted offenders who are sent to prison or jail, the average length of sentences received by those who enter prison or jail, the proportion of those who are eligible for parole that are actually released, and the percentage of parolees who are returned to prison for new crimes or parole violations. All of these factors affect the number of people in prison and, hence, the incarceration rate. A careful analysis of sentencing patterns by Pfaff shows that the dramatic increase in incarceration rates that began in the 1980s was largely due to the decision of prosecutors to 
seek prison terms for convicted individuals, and, to a lesser extent, increased sentence length and changes in parole release and revocation $[7,8]$.

In the $1980 \mathrm{~s}$, the indeterminate sentencing structures that were in place to foster the rehabilitative goals of the 1970s were replaced with determinate sentencing or truth in sentencing policies [9-11]. Across the country, state and the federal prison systems moved away from indeterminate sentencing practices and removed or restricted discretion [10]. There was also an increased use of mandatory minimum penalties for crimes $[9,10]$. Mandatory minimum penalties were easily tacked on to existing sentencing structures because they were directed at certain categories of crimes (e.g., crimes with a weapon, violent crimes). Mandatory minimum statutes mandated minimum lengths of stay, and consequently increased both the numbers of convicted offenders entering prison and the length of their sentence [9]. All of these changes influenced incarceration rates on the front-end of the criminal justice system. Changes at the back-end (reduced numbers of eligible prisoners who were granted parole and/or a higher percentage who were revoked and returned to prison) have subsequently helped maintain the high levels of incarceration [5,10]. In fact, in many states, discretionary parole was abolished. At the federal level, the Comprehensive Crime Control Act of 1984 abolished parole for inmates in federal prisons. This Act applied to any individual incarcerated in a federal institution for a crime that occurred after 1 November 1987 [9].

\section{Factors Contributing to Mass Incarceration}

Social and economic changes, especially those affecting the low income, urban, and/or minority populations, tougher sentencing practices (especially for drug crimes), and even the Civil Rights movement have been identified as plausible factors contributing to the mass incarceration that ensued $[9,10,12,13]$.

One explanation notes that the shifting social climate of the 1960s and 1970s decreased the need for low-skilled individuals in the labor force. The reduced need for these individuals occurred during a period of time that also included a booming drug trade and a growing police force. In the 1970s and early 1980s, an increased number of arrests for public order and drug offenses occurred with courts eschewing other diversionary alternatives $[12,14]$. The increasingly punitive punishment philosophy, especially toward drug offenders, drastically increased the numbers of individuals sent to prison [10,12].

Another explanation offered by Michelle Alexander notes that there is no coincidence that the beginning of the mass incarceration era occurred after the Civil Rights era when court cases and legislation granted African American and other minorities rights to contest unequal treatment in housing, education, and employment. "The New Jim Crow" refers to the dramatic increase of African Americans in prisons after civil rights supposedly ensured greater equality. The so-called War on Crime, occurring during the 1980s, arguably was a thinly veiled code for a war on minorities and the subsequent incarceration boom impacted minorities more than whites according to this view $[13,15]$.

In fact, there is troubling evidence that the mass imprisonment period was experienced differentially by whites and minorities. Now, one in three young black men are under some form of correctional supervision (prison, jail or community supervision of some sort). Especially in drug enforcement and punishment, the politics of race seem undeniable. While the majority of drug users are white, three-fourths of all arrestees are black or Hispanic ([13], p. 96). A review by Chiricos and Crawford of 38 studies published since 1975 revealed that while race did not have a direct effect on sentence 
length, convicted black offenders were more likely to be incarcerated than whites even after controlling for crime seriousness and prior record. They also showed that blacks are significantly more disadvantaged than whites in the south, where incarceration is high. Large numbers of unemployed blacks in a jurisdiction, they theorize, may be perceived as such a social and political threat as to increase the probability of incarceration [16].

Other explanations for the dramatic increase in incarceration rates obviously point to the increase in crime that occurred in the 1980s and early 1990s (although that does not explain why incarceration rates have not declined along with declining crime rates). As noted above, the nation's "drug war" has been pointed to as a causal factor; however, some analysts note that the increase in drug offenders alone could not completely explain the increase [7].

The deinstitutionalization of the mentally ill has also been suggested as a causal factor in the increased use of imprisonment [17]. As the mental institutions emptied, community mental health clinics, which were supposed to take their place, did not materialize leaving many to succumb to their illness alone and often on the street. Evidence supporting the position includes estimates that over 10 percent of this nation's prisoners have diagnosed mental illnesses and the figure is even higher in jails [5]. Even if there is no causal connection between the deinstitutionalization of the mentally ill and the increase in prison populations, it does support the notion that these social realities are due to discretionary policies that can be changed.

As noted above, the increase in the use of incarceration was not due solely or even largely to increased crime. Rather, the dramatic increase in the use of incarceration was due to a shift in policy on the part of politicians and decision-makers (prosecutors). Federal "tough on crime" reforms were set in motion by President Reagan's (1981-1989) well-publicized war on drugs. However, it should be noted that Democrats controlled both houses of Congress under President Reagan and passed the punitive laws that resulted in longer sentences.

Fear of crime was inextricably linked to societal perceptions of the prevalence of drugs in society and the relatively high violent crime rate which peaked in the early 1990s. These factors greatly influenced both parties to promote harsher laws. The use of crime as a political platform was first utilized successfully by President Nixon, but many political analysts note that President Reagan's term may be marked as the beginning of the modern use of the "crime platform" that has been such a successful campaign issue. Political benefits to championing harsher drug laws and sentencing practices were obvious, and virtually no political benefit to argue otherwise existed.

The unsuccessful 1988 presidential campaign of Michael Dukakis illustrated the potency of crime as an election issue. His failure was blamed on his stance against the death penalty and the infamous "Willie Horton" case. Horton was a prisoner who killed while out on furlough. Even though as Governor of Massachusetts, Dukakis had very little to do with the furlough decision, the tragic event was used to show how "soft" Dukakis was on crime. After this election, Democrats resolved that they could not afford to let Republicans monopolize the role of crime-fighter and the politicalization of corrections policy began in earnest [18].

Under the Clinton administration in 1994, the Violent Crime Control and Law Enforcement Act was passed, which provided 100,000 new jobs in policing as well as $\$ 7.9$ billion for the funding of new state prisons. The Violent Crime Control Act also required "truth-in-sentencing" that encouraged states to reduce or eliminate the use of parole and good time, tools used to reduce sentence length. Draconian 
provisions also created lifetime bans from federal public housing for drug offenders, more federal death penalty statutes, and federal three strikes sentences $[5,13]$.

Even after both property and violent crime began its dramatic decline in the mid-1990s, incarceration rates continued to climb. What ensued was a clash of the statisticians to determine whether or how much incarceration practices led to the crime decline. The consensus seems to be that incarceration practices were partially responsible for the dramatic decline in crime, but estimates of how much of the reduction was due to imprisonment range from one to thirty percent, and even those in the higher range seem to think now that the use of prison has reached a point of diminishing returns $[5,8]$.

\section{Effects of Mass Incarceration}

Even though the dramatic six-fold increase in incarceration over the last 30 years may have contributed to the crime decline to some extent, it has been terribly expensive for the country and its citizens. The cost of incarceration has grown exponentially [19,20]. At the federal level, the Department of Justice's (DOJ) Federal Bureau of Prisons (BOP) increased its operating cost from approximately $\$ 330$ million in the fiscal year of 1980 to almost $\$ 7$ billion requested for the 2015 budget [20]. The yearly cost of housing an inmate at the federal level ranges from approximately $\$ 21,000$ at a minimum security facility to roughly $\$ 34,000$ per inmate at a high security institution [21].

At the state level, the cost associated with prisoners has nearly quadrupled over the last two decades [19]. In a survey of 40 states in 2012, researchers at the Vera Institute found that approximately $\$ 33.4$ billion were devoted to the correctional budgets of the states surveyed [19]. Additionally, it was determined that a number of costs associated with imprisonment were neglected in these operating budgets (i.e., costs associated with employee benefits, inmate services funded through other agencies, and pensions and retiree health care plans), and the true cost of incarceration for the forty states surveyed in the fiscal year of 2010 was closer to $\$ 38.9$ billion [19].

The cost of incarceration on families is harder to measure, but no less serious. Mass incarceration has resulted in a number of "invisible consequences" ([22], p. 74; [23]). There are now an estimated 2.7 million children with parents in prison. It has become such a noted social problem that Sesame Street, a noted children's television program, has responded with a character that represents these children of incarcerated parents [24]. Children of incarcerated parents experience disrupted households and are more likely than other children to be exposed to risk factors including extreme poverty, substance abuse, maltreatment, and homelessness [22,25-27]. Additionally, children with incarcerated parents have been linked to higher levels of delinquent/criminal activity later in life, greater levels of incarceration and/or conviction of crimes, higher levels of antisocial behavior, greater numbers of psychological problems, and/or diminished cognitive abilities [28-33].

Poor urban communities tend to be disproportionately impacted by the nation's reliance on incarceration [34]. Researchers argue that the high rates of incarceration that characterize these communities have negative effects (e.g., lower levels of social organization, unstable families, and a diminished opportunity structure) that outweigh any positive effects (e.g., reduced crime) $[23,34]$.

An important cost that seems to have been derived from the zealous drive to punish may be an unknown number of individuals who were wrongfully incarcerated and convicted. The Innocence Project, with teams of attorneys around the country and other efforts to investigate and litigate 
convictions, has aided in the exoneration of 1536 individuals through DNA testing or other means [35]. These individuals have served decades in prison for crimes they did not commit due to unintentional errors and/or misconduct on the part of law enforcement and prosecutors. Others may have been factually guilty, but missteps in the justice system hindered due process to the extent that their convictions were overturned. It will never be known whether or not they were guilty. Mistaken eyewitness testimony, false confessions (due to mental illness and/or coercion), perjured testimony, and suppressed evidence (Brady violations) are some of the major reasons identified in these wrongful conviction cases [36,37].

Some state legislatures have passed statutes mandating compensation for each year of imprisonment to the exonerated individual. Texas, for instance, pays $\$ 80,000$ per each year of wrongful imprisonment to the exonerated, resulting in a tab of $\$ 65$ million to 89 exonerated individuals by 2013 [38]. While the costs to states because of wrongful imprisonment are not insubstantial, the cost to the individual and their families is incalculable as is the cost to the justice system itself since the ever-increasing numbers of the exonerated continues to reduce the trust citizens have in the criminal justice system.

\section{Calls in the Wilderness: Liberal Support for Diversion}

It should not go unnoted that there has been longstanding opposition to the use of imprisonment as a first-choice sentencing option, especially for drug users. The Drug Policy Foundation (created in 1987) and the Lindesmith Center (started in 1994) (now merged as the Drug Policy Alliance) have always advocated a harm reduction policy for drug addicts rather than imprisonment. The National Council on Crime and Delinquency has also had a longstanding position that only a small portion of prisoners need to be incarcerated to protect the public [39,40]. The American Friends Service Committee, a Quaker organization, has been involved in prison reform and even abolition attempts almost from the inception of prisons and was quite active in the 1970s in attempting to promote alternatives to prison $[41,42]$.

A small but steady drumbeat from academics has voiced support for rehabilitation over punishment continuously since the late 1970s showing that rehabilitative programs in prison show some success, albeit not for all prisoners [43-47]. Other academics noted the deleterious effects of imprisonment [48,49], and how, historically, it had been used in small doses for the worst offenders [50]. It was also academics who first identified and analyzed the political shift toward punitiveness as a correctional philosophy, concluding the movement was not in the best interests of society [39].

By the 1990s, journalists began exploring the "prison industrial complex", examining the link between economics and prisons [51]. Christian Parenti and others described how small towns solicited states or private vendors to build prisons and the negative economic impact it has had overall on states' economies [52]. By the late 1990s, critics of this nation's reliance on prisons had been disseminating their views for over 20 years. Evidently, these criticisms were falling on deaf ears either because of ignorance, apathy, or venal interests that were contrary to the position that prisons were not the answer to societal problems and, in fact, presented their own host of problems.

\section{The Conservative Shift from Harsh Justice}

When President Obama noted in his January 2015 State of the Union address that it was time to consider how to reduce the nation's dependence on prison, it may have been the first time the topic 
was broached in such a forum. The position that the mass imprisonment and "tough on crime" approach needs to be addressed is not surprising coming from a "liberal" Democrat. What is interesting is that it is a position held increasingly by extremely conservative national and local figures. Charles Colson (a Watergate figure), Grover Norquist (tax reform advocate), Newt Gingrich (conservative politician and pundit), Bernard Kerik (ex-commissioner of N.Y.P.D.), and even Charles Koch (conservative political donor) could never be mistaken as advocates for liberal causes, yet each has promoted crime policies that are contrary to the "tough on crime" approach that characterized crime policy in the United States since the 1980s.

Conservatives now support reducing or eliminating mandatory minimum and three-strikes sentencing, and support "ban the box" initiatives which would prohibit requiring individuals to admit prior arrests in job applications. Conservative support for sentencing reforms has enabled reductions in prison populations in several states and allowed national initiatives to move forward. While it is encouraging that criminal justice reform may indeed be possible given this support by noted conservative voices, it is important to look closer at what exactly is happening. We will begin the process of deconstructing this political shift by asking four relevant questions: What does the movement look like? What changes will it insist upon? What are its motivations? And, how durable is it?

\subsection{What Does the Movement Look Like?}

The emergence of conservative advocates for crime policy reform does not mean that there is a unified national movement that has been consistently and comprehensively successful at the state level. Rather, this shift began with individuals and has only recently developed into political action organizations.

Perhaps it is not coincidental that the first conservative voices who questioned the use of prisons and the lack of any sincere rehabilitative goals in our corrections system were those who had spent time in prison themselves: Charles Colson, an aide to President Nixon convicted of his role in the Watergate scandal, spread Christianity among prisoners and devoted his life to criminal justice reform after serving seven months in 1974 for obstruction of justice. His Justice Fellowship organization advocates prison reform. The head of the Justice Fellowship is Pat Nolan, a former conservative Republican in the California assembly, became an advocate for prison reform after serving 29 months for corruption in the 1990s [53]. Duke Cunningham, who served time for public corruption in 2005, has also spoken for prison reform, as has right-wing media mogul Conrad Black who served two years after being convicted in 2007 for fraud [54-57].

The single conservative voices advocating for a shift in correctional policy from harsh punishment to reform continues, but the movement has recently coalesced under the "Right on Crime" banner, created by Marc Levin of the Texas Public Policy Foundation. On 15 December 2010, the Right on Crime initiative launched its national campaign in Washington, D.C. with the support of Republican politicians Newt Gingrich and Pat Nolan. The Texas Public Policy Foundation is a conservative policy-based research agency based in Austin, Texas. According to the Right on Crime website, the project is committed to limited government, free markets, individual liberty, and personal responsibility [56,57].

In a 2011 op-ed piece for the New York Times, Gingrich and Nolan stated that the campaign represents a seismic shift in the legislative landscape and opens the door for common-sense left-right 
agreement on an issue that has kept the parties apart for decades. They write, "We can no longer afford business as usual with prisons. The criminal justice system is broken, and conservatives must lead the way in fixing it" [58]. Thus, the movement is both a well-organized and national-level policy advocacy machine (the "Right on Crime" organization) as well as a growing group of conservatives who express support for justice reform-either through their legislative activities (Rand Paul) or through their individual activities (Charles Koch or Grover Norquist).

\subsection{What Changes Will It Insist upon?}

Rand Paul, a potential Presidential contender for the 2016 election, recently insisted that "we must demilitarize our police" in the public discussion after the Michael Brown shooting by Officer Wilson in Ferguson, Missouri [59]. Instead of the predictable drawing of sides in this latest dispute, some conservatives have publicly agreed that there must be some shift in policing tactics. While Paul's stand on the "demilitarization" of policing does not reflect the mainstream of conservative crime policy, support for reducing mandatory minimums seems to be widespread (e.g., the Smarter Sentencing Act).

Reducing the prison population, both at the federal level and in state systems, is a clear goal of the conservative proponents for reform. To reach that goal, there has been public support for changes in sentencing laws and funding for re-entry programs (e.g., the National Reentry Act). Further, there is a strong push for reducing the number of laws. While most conservatives do not go as far as advocating the decriminalization of marijuana; there is increasing support (or reduced opposition to) medical marijuana laws. More consistent with the conservative agenda, however, is the campaign to reduce the number of laws or ability of federal and state prosecutors to pursue white collar and regulatory crimes.

\subsection{What Are Its Motivations?}

Obviously there are sometimes differences between open and hidden agendas. With this caveat, we look to the statements of the major proponents of the conservative shift, but also speculate about the political agenda behind recent actions. We can identify at least four clear and not-so-clear motivations: fiscal savings, personal redemption values, reducing governmental reach, and appealing to "swing" and independent voters, especially minorities, who must replace the base of the Republican voting electorate for future races.

There is no doubt that fiscal savings drives much of the conservative support for criminal justice reform. In the past, conservative Republicans, perennial advocates of smaller government, always exempted the military and policing from calls to cut government spending. With bloated correctional and justice-system budgets taking greater and greater portions of state budgets, there has been increasing pressure to find savings - even in these sacred-cow areas of governmental spending.

Republican governors, faced with ever-increasing correctional budgets, reached a point after the Great Recession beginning in 2007, when the burden of large budget deficits spurred re-thinking the ever-increasing corrections' budgets [56,57]. There is clear evidence that adjusting sentencing statutes can result in massive savings, and such changes can be directed at non-violent offenders with predictable public support. By redrawing the justice and corrections systems as examples of the expensive and ineffective government agencies that conservatives traditionally disdain, advocates for change can avoid the liberal label. 
One of the important elements of the fiscal savings position is that there is better evidence for alternatives to imprisonment. A former Attorney General of Virginia, Ken Cuccinelli, and Deborah Daniels, a former U.S. Assistant Attorney General under President Bush, expressed the sentiment that research evidence should be considered when forming correctional policies in an op-ed quoting research findings:

The Pew Charitable Trusts recently reported that states that have cut their imprisonment rates (coupled with other reforms) have experienced a greater crime drop than those that increased incarceration. Between 2007 and 2012, the 10 states with the largest decreases in imprisonment rates had a 12 percent average reduction in crime, while the 10 states with the largest imprisonment rate increases saw crime fall 10 percent [60].

Alexander $[13,15]$ persuasively argues that the dramatic shift away from the get-tough rhetoric by conservatives has been fueled not by a concern about the devastating consequences to a large segment of the population. Rather the change is a result of changes in perceived white interests, specifically fiscal austerity is attractive to white voters who are tired of paying for prisons. Pure economics dictates that continued dependence on mass incarceration conflicts with perceived white interests [15]. Conservative politicians are unwilling to risk alienating their supporters by raising taxes, and thus must appeal to their constituents by showing that reducing prison populations is consistent with a conservative platform [15].

In addition to fiscal restraint, another traditional conservative value is individual redemption. Recall that early voices such as Charles Colson and Pat Nolan emerged from prison as reformers. Bernard Kerik, ex-commissioner of N.Y.P.D., also emerged from prison as a reformer after he served a short prison sentence for fraud and other crimes. These gentlemen have expressed their surprise over who they met in prison; they realized that many prisoners were not evil nor even dangerous and that many simply deserved a second chance at life [61].

In a National Public Radio (NPR) radio interview, Marc Levin from the Right on Crime campaign and Mark Mauer, the director of the Sentencing Project, a liberal policy institute that advocates sentencing alternatives, agreed on many issues. Levin voiced the values rhetoric that overlays and accompanies fiscal reasons for conservative support for reduced imprisonment.

I think there's also - in addition to the fiscal motivations, there are also motivations of, look, I mean, every major religious faith believes in redemption and the opportunity for people to turn their lives around and not every offender is amenable to rehabilitation, but many are.

...I mean there's been a mountain of research over the last few decades that has shown that different alternatives to prison work, whether it's problem-solving courts, electronic monitoring, treatment diversions for the mentally ill, we've had huge advances in risk assessment instruments that can better match offenders with the right programs [62].

Another motivation for conservative support is that targeting the criminal justice system as the problem (for good people), as opposed to the solution (to street crime), tracks well with the emerging opposition to "over-criminalization". This position basically states that federal and state governments have gone too far, and the myriad of laws trap the unwary. Respected think tanks from the left, the 
center, and the right have all recently noted the problem of too many laws. Strict liability federal crimes have been especially targeted as evidence of an out-of-control government.

It is probably not coincidental that some of the conservative voices for reform have been caught up as federal defendants. Charles Koch, for instance, an extremely conservative and powerful Republican donor, was interviewed recently about his support and advocacy for criminal justice reforms. It seemed that his support for reform emerged from his own troubles with federal prosecutors which led to spending "tens of millions" of dollars in defense costs and a settlement of \$10 million. Koch observes that the "little guy" has no resources when the government goes on the attack and has reportedly donated a large sum of money to the National Association of Criminal Defense Attorneys. He pledges support for restoring voting rights for non-violent ex-convicts and expunging criminal records of minors, but his major emphasis seems to be that the federal justice system (and presumably states) have become too overbearing on people who do not pose a threat to the public. As a philosophical support for reducing the reach of criminal law, this resonates with both non-violent drug offenders as well as multi-millionaires who yearn for fewer regulatory crimes [63].

A final motivation is purely speculative and that is there is a political agenda to the championing of prison and crime policy reform. Some may remember that there was widespread speculation that if President Clinton had shown more leadership in encouraging a reduction in the use of prison rather than paying states to build more of them, then Al Gore might have won Florida and the presidency. Pundits and academics pointed to the incredible toll that prison and "collateral consequences", including lifetime bans on voting in some states, had taken on black communities who typically voted Democratic. Statistics indicate that if even a modest percentage of incarcerated or formerly incarcerated Blacks had been able to vote, Democrats would have won not just the popular, but also the electoral votes for Florida in the 2000 presidential election [5,13]. Whether this was true or not, it is clear that prison reform, harm reduction policies, and alternatives to prison are issues that resonate in the minority communities who have seen proportionally more of their members disappear behind prison walls.

It is at least conceivable that as the country trends more and more toward a diverse population with minorities increasing their share of the electorate, conservative Republicans realize that the law-and-order platform that had worked well for them in prior decades would need to be replaced with one that was more attractive to independent and, especially, minority voters. A glimmer of the validity of this rationale appears in a quote by Marc Levin noted by the journalist interviewing him:

But as Levin points out, there's just one last thing for Republicans and Democrats working on the issue to sort out: "The only disagreement sometimes is who's gonna get the credit." ([18], p. 1).

The discussion above points out that there may be strategic reasons to champion reform in addition to fiscal restraint. It is also true that what drives the conservative shift may be different for different people. Those conservatives who served time in prison may indeed believe in supporting opportunities for personal redemption that mirror their own life. After all, they saw first-hand that our prisons are filled mostly with men (and women) who had very few choices in life and managed to make the worst ones possible. Other conservative advocates for prison alternatives may see only dollars and cents, and still others may be crunching the poll numbers that show Americans are more and more favorably disposed to rehabilitation [5]. 


\subsection{How Durable Is It?}

Whether or not this conservative shift away from harsh punishment "has legs" (remain viable) remains to be seen. Will conservative politicians continue to advocate closing prisons when crime rates tick up? Will they stand up to the vested interests that have profited from bloated correctional budgets? Indeed, does a philosophical foundation based on personal redemption and fiscal restraint, without a concomitant recognition and admission that the last thirty years have been at least partially the result of racial and economic inequalities, provide a solid enough base to go forward?

Some have expressed a concern that the emerging conservative support for reducing mass imprisonment is based solely on economics which will surely lead to a return to punitive policies. First, because alternatives to prison are not cheap either, and if there is no corresponding shift in correctional budgets from prisons to community-based treatment options, then newly released offenders are bound to fail. Second, as the economy continues to improve, the pressure to find alternatives to prison in order to reduce correctional costs will dissipate [13].

It is abundantly clear that the almost twenty year decline in crime has eased the pressure to maintain a "tough on crime" political platform. Many people are now aware of 30-year lows in some violent crimes and recent federal statistics continue to show decreases in many crime categories. Dramatically reduced crime rates has translated into polls that show that the American public does not place fear of crime high on their list of concerns and, consequently, there is now the opportunity to broach new directions [59]. However, if crime increases significantly, then the standard answer to public concern may revert to the perennial "lock-them-up".

Interestingly, the "prison issue" is somewhat similar to the immigration issue for Republicans. While some Republicans (President Bush, Mark Rubio of Florida) seem or seemed to be willing to reach across the aisle for moderate resolutions, they have to navigate a position that speaks to the Hispanic community, while at the same time does not alienate conservative white voters who feel immigration threatens jobs. Similarly, the prison issue presents a difficult position for conservatives who advocate for second chances for offenders while their middle class constituents' inclinations towards mercy for offenders only goes so far. Thus, the personal redemption script is bolstered by the fiscal savings that result from successful diversion.

The movement provides much-needed political cover for Republican politicians who face district attorney associations, correctional and law enforcement officer unions, and other vested interests when they advocate sentencing reform and/or closing prisons; however, if push-back becomes too strong, it may be politically dangerous to advocate for "soft" solutions to crime. On the other hand, careful analysis has shown that the public's thirst for vengeance and support for harsh justice beginning in the 1960s was, at least partially, orchestrated for political gain [15,64]. If true, then it is certainly conceivable that the conservative shift to easing the "harsh justice" approach to social problems and offering second chances to offenders may not just be reflecting public opinion, but could also help shape it.

\section{Local versus National Venues}

Before concluding the discussion, it is important to note that justice reform at the national level may or may not affect state policies; furthermore states are very different in the particular mix of 
personalities and pressures that affect legislative change. There is no doubt that national agendas influence what occurs in states. For instance, President Clinton signed into legislation incentives for prison building rather than rehabilitative research at the state level, increasing the number of prisons [13]. It is also the case, however, that states are wildly different in their sentencing patterns with some states incarcerating twice as many residents as others [5]. In recent years, while some states have reduced their prison populations other state prison populations have increased indicating there is, as yet, no consistent national trend.

On the national stage, the "Right on Crime" and conservative shift is increasingly visible. The recent Conservative Political Action Committee (CPAC) meeting near Washington, D.C., in addition to other conservative causes, presented criminal justice reform as a Republican issue. Bernard Kerik, Rick Perry (ex-governor of Texas), and other noted conservatives argued for reform. Their stance was that liberals had zero credibility with the public on criminal justice reform and only conservatives could successfully champion reform [61]. Senator Rand Paul has co-sponsored legislation that offers alternatives to sending juveniles into the justice system and includes a provision for sealing the records of the formerly incarcerated. In the upcoming presidential election, it is likely that the crime policy portion of the national and state platforms will take a different slant from previous years as each side calibrates their position in order to appeal to the widest range of voters.

On a state level, Texas is an example of how justice reform can be successful in a deeply conservative state. Governor Perry signed the Michael Morton Act, named after a man exonerated for killing his wife when DNA evidence was tested, that required prosecutors to have an open file policy with defense attorneys. The state offers the highest per-year reimbursement for the wrongfully convicted. Texas was a model for national initiatives to divert funds from prison construction to community sentencing alternatives and reduced its prison population leading to the closure of several prisons [65]. Opposition has emerged from the statewide associations of district attorneys and some law enforcement associations, but continued reductions in crime rates bolster efforts to continue to find ways to reduce the number of individuals being sent to prison. Texas legislators have been successful in reducing the prison population while maintaining the appearance of "toughness". Space prohibits an analysis of how this has occurred or what is likely to happen now that the state has a new governor, nor is there an opportunity to explore other states particular political atmosphere for how these reforms may be received. It must be sufficient to note that national, state, and local influences shape criminal justice policies.

\section{Conclusions}

This paper tracked our thirty year dependence on incarceration as the first choice option for punishment and correction. We have seen a six-fold increase in incarceration rates since 1980 and this increase has been experienced differentially by minorities. In the last ten years or so, increasing numbers of conservative voices have joined a chorus supporting sentencing reform, prison alternatives, and crime policy reforms based on a multi-faceted rationale of fiscal restraint, personal redemption, and reducing governmental reach (overcriminalization). We offer an unstated but potentially viable hidden rationale in asking whether conservative politicians are recognizing and responding to the growing power of the minority electorate. 
Advocating justice reform without recognizing the role of social, political, and economic structural inequalities of this society may not only be cynical, but unsuccessful in controlling the Frankenstein of the prison-industrial complex and the public's habituation to mass incarceration. To maintain a criminal justice system free of mass incarceration, there must be not only support based on economic or political logic, but also a socio-political rationale that is based in fundamental freedoms and human rights. The massive shift in the use of prison was not smart, it was not necessary (to the extent that it took place), and it was not fair. All human beings have the right to be treated fairly by their justice system with punishment allotted not by their skin color or bank account. All human beings have the right to due process without fear or favor. A national recognition of these rights and an acknowledgement that we did not uphold them in the last thirty years seems to be the first step in dismantling the mass imprisonment that began in the 1980s.

\section{Acknowledgements}

The authors wish to thank the anonymous reviewers for their comments and suggestions. They wish also to thank Robert Johnson for his encouragement to write this article.

\section{Author Contributions}

Joycelyn Pollock created the idea for and outline of the article. Steven Glassner researched and wrote a draft of the increase in incarceration rates and Andrea Krajewski researched and wrote a draft of the Rise on Crime section of the article. Joycelyn Pollock revised and added additional information. All authors helped to respond to reviewer comments and approved the final version of this article.

\section{Conflicts of Interest}

The authors declare no conflict of interest.

\section{References}

1. International Centre for Prison Studies. "Highest to lowest_-Prison population rate." Available online: http://www.prisonstudies.org/highest-to-lowest/prison_population_rate (accessed on 22 October 2014).

2. E. Ann Carson. "Prisoners in 2013." September 2014. Available online: http://www.bjs.gov/ content/pub/pdf/p13.pdf (accessed on 22 October 2014).

3. E. Ann Carson, and Daniela Golinelli. "Prisoners in 2012-Advance counts." July 2013. Available online: http://www.bjs.gov/content/pub/pdf/p12ac.pdf (accessed on 22 October 2014).

4. Paul Guerino, Paige M. Harrison, and William J. Sabol. "Prisoners in 2010." February 2012. Available online: http://www.bjs.gov/content/pub/pdf/p10.pdf (accessed on 22 October 2014).

5. Joycelyn Pollock. Prisons and Prison Life: Costs and Consequences. New York: Oxford University Press, 2013.

6. Justice Policy Institute. "The punishing decade: Prison and jail estimates at the millennium." May 2000. Available online: http://www.justicepolicy.org/images/upload/00-05_rep_punishingdecade_ ac.pdf (accessed on 22 October 2014). 
7. John Pfaff. "The micro and macro causes of prison growth." Georgia State University Law Review 28 (2011): 1237-72.

8. Steven Raphael, and Michael Stoll. Do Prisons Make Us Safer? The Benefits and Costs of the Prison Boom. New York: Russell Sage Foundation, 2008.

9. Nathan James. "The federal prison population buildup: Overview, policy changes, issues, and options." April 2014. Available online: http://fas.org/sgp/crs/misc/ R42937.pdf (accessed on 22 October 2014).

10. Joan Petersilia. "Prisoner reentry: Public safety and reintegration challenges." The Prison Journal 81 (2001): 360-75.

11. Katherine J. Rosich, and Kamala Mallik Kane. "Truth in sentencing and state sentencing practices." National Institute of Justice Journal 252 (2005): 18-21. Available online: http://www.nij.gov/journals/252/Pages/sentencing.aspx (accessed on 22 October 2014).

12. Christopher Wildeman, and Bruce Western. "Incarceration in fragile families." Future of Children 20 (2010): 157-77.

13. Michelle Alexander. The New Jim Crow: Mass Imprisonment in the Age of Colorblindness. New York: The New Press, 2010.

14. Bruce Western. Punishment and Inequality in America. New York: Russell Sage Foundation, 2006.

15. Michelle Alexander. "In prison reform, money trumps rights." New York Times, 14 May 2011. Available online: http://www.nytimes.com/2011/05/15/opinion/15alexander.html?pagewanted=all (accessed on 23 October 2014).

16. Ted Chiricos, and George Crawford. "Race and imprisonment: A contextual assessment of the evidence." In Ethnicity, Race and Crime: Perspectives across Time and Place. Edited by Darnell F. Hawkins. Albany: SUNY Press, 1995, pp. 281-309.

17. Marie Gottschalk. The Prison and the Gallows: The Politics of Mass Incarceration in America. Cambridge: Cambridge University Press, 2006.

18. Emma Roller. "How Republicans Stopped Being 'Tough on Crime'." National Journal Daily, 2 October 2014. Available online: http://www.nationaljournal.com/congress/how-republicansstopped-being-tough-on-crime-20141001 (accessed on 22 October 2014).

19. Christian Henrichson, and Ruth Delaney. "The price of prisons: What incarceration costs taxpayers." July 2012. Available online: http:/www.vera.org/sites/default/files/resources/ downloads/Price_of_Prisons_updated_version_072512.pdf (accessed on 22 October 2014).

20. U.S. Government Accountability Office. "Bureau of Prisons: Information on efforts and potential options to save costs." September 2014. Available online: http://www.gao.gov/assets/670/ 666254.pdf (accessed on 22 October 2014).

21. Nancy La Vigne, and Julie Samuels. "The growth and increasing cost of the federal prison system: Drivers and potential solutions." December 2012. Available online: http://www.urban.org/ uploadedpdf/412693-the-growth-and-increasing-cost-of-the-federal-prison-system.pdf (accessed on 22 October 2014).

22. Christopher Wildeman. "Parental incarceration, child homelessness, and the invisible consequences of mass imprisonment." The ANNALS of the American Academy of Political and Social Science 65 (2014): 74-96. 
23. Marc Mauer, and Meda Chesney-Lind, eds. Invisible Punishments: The Collateral Consequences of Mass Imprisonment. Washington: The Sentencing Project, 2002.

24. Julie Reilly. "Sesame Street reaches out to 2.7 million American children with an incarcerated parent." Pew Research Center, 22 June 2013. Available online: http://www.pewresearch.org/facttank/2013/06/21/sesame-street-reaches-out-to-2-7-million-american-children-with-anincarcerated-parent/ (accessed on 22 October 2014).

25. National Conference of State Legislators. "Children of incarcerated parents." May 2009. Available online: http://www.ncsl.org/documents/cyf/childrenofincarceratedparents.pdf (accessed on 22 October 2014).

26. Michael E. Roettger, Raymond R. Swisher, Danielle C. Kuhl, and Jorge Chavez. "Parental incarceration and trajectories of marijuana and other illegal drug use from adolescence into young adulthood: Evidence from longitudinal panels of males and females in the United States." Addiction 106 (2010): 121-32.

27. Joycelyn Pollock. Women's Crimes, Criminology and Corrections. Long Grove: Waveland Press, 2014.

28. Joyce A. Arditti. Parental Incarceration and the Family: Psychological and Social Effects of Imprisonment on Children, Parents, and Caregivers. New York: New York University Press, 2012.

29. Beth M. Huebner, and Regan Gustafson. "The effect of maternal incarceration on adult offspring involvement in the criminal justice system." Journal of Criminal Justice 35 (2007): 283-96.

30. Joseph Murray, David P. Farrington, and Ivana Sekol. "Children's antisocial behavior, mental health drug use, and educational performance after parental incarceration: A systematic review and meta-analysis." Psychological Bulletin 138 (2012): 175-210.

31. Emily B. Nichols, and Ann B. Loper. "Incarceration in the household: Academic outcomes of adolescents with an incarcerated household member." Journal of Youth and Adolescence 41 (2012): 1455-71.

32. Ross Parke, and K. Alison Clarke-Stewart. "Effects of parental incarceration on young children." 2001. Available online: http://www.urban.org/UploadedPDF/410627_ParentalIncarceration.pdf (accessed on 22 October 2014).

33. Megan Comfort. "Punishment beyond the legal offender." Annual Review of Law and Social Science 3 (2007): 271-96.

34. Jeffery D. Morenoff, and David J. Harding. "Incarceration, prisoner reentry, and communities." Annual Review of Sociology 40 (2014): 411-29.

35. Innocent Project. "About the Organization.” Available online: http://www.law.umich.edu/special/ exoneration/Pages/Exoneration-by-Year.aspx (accessed on 26 January 2015).

36. Brandon Garrett. Convicting the Innocent: Where Criminal Prosecutions Go Wrong. Cambridge: Harvard University Press, 2011.

37. Tiffany Cox, Shannon Cunningham, and Joycelyn Pollock. "A closer look at prosecutor misconduct and good faith error." Unpublished work, 2014.

38. Mike Ward. "Tab for wrongful convictions in Texas: $\$ 65$ million and counting." Austin American Statesman, 10 February 2013. Available online: http://www.statesman.com/news/news/tab-forwrongful-convictions-in-texas-65-million-a/nWLQM/ (accessed on 22 October 2014).

39. Franklin Zimring, and Gordon Hawkins. Imprisonment. London: Oxford Publishing Company, 1997. 
40. Nora Klapmuts. Community Alternatives to Prison. Hackensack: National Council on Crime and Delinquency, 1973.

41. David S. Greenberg. The Problem of Prisons. Philadelphia: American Friends Service Committee, 1970.

42. American Friends Service Committee. Struggle for Justice: A Report on Crime and Punishment in America. New York: Hill \& Wang, 1971.

43. Paul Gendreau, and Robert Ross. "Effective correctional treatment: Bibliotherapy for cynics." Crime and Delinquency 25 (1979): 463-89.

44. Paul Gendreau, and Robert Ross. Effective Correctional Treatment. Toronto: Butterworth Publishing, 1980.

45. Paul Gendreau, and Robert Ross. "Revivication of Rehabilitation: Evidence from the 1980s." Justice Quarterly 4 (1987): 349-407.

46. Frank Cullen. Reaffirming Rehabilitation. Cincinnati: Anderson, 1982.

47. Ted Palmer. A Profile of Correctional Effectiveness and New Directions for Research. Albany: SUNY Press, 1994.

48. Norval Morris. The Future of Imprisonment. Chicago: University of Chicago Press, 1974.

49. William G. Nagel. The New Red Barn: A Critical Look at the Modern American Prison. New York: Walker and Company, 1973.

50. Robert Johnson. Hard Time: Understanding and Reforming the Prison. Belmont: Wadsworth Publishing, 1987.

51. Eric Schlosser. "The Prison Industrial Complex.” The Atlantic, December 1999. Available online: http://www.theatlantic.com/magazine/archive/1998/12/the-prison-industrial-complex/304669/ (accessed on 23 October 2014).

52. Christian Parenti. Lockdown America: Police and Prisons in the Age of Crisis. New York: Verso New Left Books, 1999.

53. Pat Nolan. "Testimony of Pat Nolan before the U.S. Sentencing Commission." June 2014. Available online: http://www.ussc.gov/sites/default/files/pdf/amendment-process/public-hearings-and-meetings/ 20140610/TestimonyNolanRevised.pdf (accessed on 22 October 2014).

54. David Weigel. "Forgive and forget: On drug sentencing, a growing number of Republicans are ready to shed the party's law and order image in favor of reform." Slate, 6 February 2014. Available online: http://www.slate.com/articles/news_and_politics/politics/2014/02/republicans_ are_favoring_going_easy_on_drug_offenders_the_young_gop_leaders.single.html (accessed on 20 October 2014).

55. Martha Moore. "Conservatives, liberals unite to cut prison populations." USA Today, 17 March 2014. Available online: http://www.usatoday.com/story/news/politics/2014/03/16/conservativessentencing-reform/6396537/ (accessed on 20 October 2014).

56. Shane Bauer. "How Republican conservatives learned to love prison reform." Mother Jones, April 2014. Available online: http://www.motherjones.com/politics/2014/02/conservatives-prisonreform-right-on-crime (accessed on 20 October 2014).

57. David Dagan, and Steven M. Tele. "The conservative war on prison." Washington Monthly, November-December 2012. Available online: http://www.washingtonmonthly.com/magazine/ 
novemberdecember_2012/features/the_conservative_war_on_prison041104.php?page $=$ all\# (accessed on 20 October 2014).

58. Newt Gingrich, and Pat Nolan. "Prison reform: A smart way for states to save money and lives." The Washington Post, 7 January 2011. Available online: http://www.washingtonpost.com/wpdyn/content/article/2011/01/06/AR2011010604386.html (accessed on 22 October 2014).

59. Peter Betnartaug. "This time it's different: The conservative response to Ferguson." The Atlantic, August 2014. Available online: http:/www.theatlantic.com/politics/archive/2014/08/this-time-itsdifferent-the-conservative-response-to-ferguson/378546/ (accessed on 21 January 2015).

60. Ken Cuccinelli, and Deborah Daniels. "Less incarceration could lead to less crime." Washington Post, 19 June 2014. Available online: http://www.washingtonpost.com/opinions/less-incarceration-couldlead-to-less-crime/2014/06/19/03f0e296-ef0e-11e3-bf76-447a5df6411f_story.html?hpid=z6 (accessed on 22 October 2014).

61. Alex Seitz-Wald, and Elahe Izadi. "Criminal justice reform, brought to you by CPAC." The National Journal, March 2014. Available online: http://www.nationaljournal.com/domesticpolicy/ criminal-justice-reform-brought-to-you-by-cpac-20140307 (accessed on 25 January 2015).

62. Marc Levin. "Is 'tough on crime' no longer a talking point?" National Public Radio, 20 September 2012. Available online: http://www.wbur.org/npr/161475623/is-tough-on-crime-no-longer-atalkingpoint? $\mathrm{ft}=3 \& \mathrm{f}=161475623$ (accessed on 22 October 2014).

63. Roy Wenzl. "Charles Koch's views on criminal justice system just may surprise you." Wichita Eagle, 27 December 2014. Available online: http://www.kansas.com/news/special-reports/koch/ article 5050731.html\#storylink=cpy (accessed on 21 January 2015).

64. Katherine Beckett, and Theodore Sasson. The Politics of Injustice: Crime and Punishment in America. Pine Forge: Sage Publications, 2004.

65. Mike Ward. "Officials: Two Private Prisons to /Close." Austin American Statesman, 11 June 2013. Available online: http://www.statesman.com/news/news/officials-two-private-prisons-toclose/nYH3w/ (accessed on 16 March 2015).

(C) 2015 by the authors; licensee MDPI, Basel, Switzerland. This article is an open access article distributed under the terms and conditions of the Creative Commons Attribution license (http://creativecommons.org/licenses/by/4.0/). 